\title{
EVALUATION OF FLAX (Linum usitatissimum L.) GENOTYPES ON ENVIRONMENTAL ADAPTABILITY AND STABILITY IN THE NORTH-EASTERN BELARUS
}

\section{K.P. KOROLEV1, N.A. BOME ${ }^{2}$}

\author{
${ }^{1}$ The Institute of Flax NAS of Belarus, ag. Ust'e, Orshanskii Region, Vitebsk Province, 211003 Republic of Belarus, \\ e-mail corolev.konstantin2016@yandex.ru; \\ ${ }^{2}$ Tyumen State University, 6, ul. Volodarskogo, Tyumen, 625003 Russia, e-mail bomena@mail.ru (corre- \\ sponding author) \\ ORCID: Bome N.A. orcid.org/0000-0002-8496-5365 \\ The authors declare no conflict of interests
}

Received January 19, 2017

Abstract

Flax is the only industrial crop cultivated in Belarus for fiber on the area over 50 thousand ha. An environmental adaptation is of special interest for innovative flax varieties. We focused on selection of genetic sources of adaptability and stability and the search for environmentally adapted genotypes among the extensive flax hybrids. For this, we have studied a response of the parent forms and 36 hybrid populations of fiber flax to abiotic factors and estimated the influence of environment on economically important traits. The field trials (Orshanskii Region, Belarus, 2012 to 2014) were carried out under weather conditions which varied in precipitations $(16.7-27.1 \mathrm{~mm})$ and daily air temperature (12.4-16.4 ${ }^{\circ} \mathrm{C}$ ). Plant height, stem technical length, weight, and fiber content were studied in 10 parental varieties different in geographic origin (i.e. derived from Belarus, Russia, France, Ukraine, Lithuania), and also in their combinations. Morphological and biological screening identified 11 early ripening combinations, 15 forms with tall stem, 10 forms with a significant technical stem length, 4 ones with high stem weight, and 3 ones with high fibre content. A statistically significant impact (at 95 and $99 \%$ level) of genotypes $\left(\mathrm{F}_{\mathrm{o}}>\mathrm{F}_{\mathrm{e}}\right)$, environment factor and their interactions (genotype $\times$ environment) have been found. The estimation of stability and responsiveness to environmental conditions of each of the studied flax genotypes by Eberhart and Russell method revealed that high responsiveness to the improved growing conditions was characteristic of Alizee $\left(b_{i}=1.12\right)$, Upite $2\left(b_{i}=1.22\right)$, Lvovskiy 7 $\left(b_{i}=1.02\right)$, Lvovskiy $7 \times$ Yarok $\left(b_{i}=1.79\right)$, Lvovskiy $7 \times$ Voskhod $\left(b_{i}=3.07\right)$ for plant height, $\mathrm{K}-$ $65\left(b_{i}=1.33\right)$, Velich $\left(b_{i}=1.12\right)$, Upite $2\left(b_{i}=1.22\right)$ Lvovskiy $7\left(b_{i}=1.32\right)$, Yarok $\times K-65\left(b_{i}=1.87\right)$, K-65 $\times$ Laska $\left(b_{i}=1.37\right)$, Yarok $\times$ Velich $\left(b_{i}=2.09\right)$ for technical stem length; Voskhod $\left(b_{i}=2.38\right)$, Laska $\left(b_{i}=1.85\right), K-65\left(b_{i}=1.76\right)$, Voskhod $\left(b_{i}=2.32\right)$, Yarok $\times$ Laska $\left(b_{i}=1.87\right)$, Laska $\times$ Voskhod $\left(b_{i}=2.16\right)$, Voskhod $\times$ Alizee $\left(b_{i}=1.17\right), K-65 \times$ Laska $\left(b_{i}=1.31\right)$ for stem weight; Laska $\left(b_{i}=1.14\right)$, Voskhod $\left(b_{i}=1.27\right)$, Drakkar $\left(b_{i}=1.59\right), K-65\left(b_{i}=1.32\right)$, Vasilek $\left(b_{i}=1.39\right)$, Yarok $\times$ Laska $\left(b_{i}=2.54\right)$, Yarok $\times$ Voskhod $\left(b_{i}=1.78\right)$, Velich $\times \operatorname{Voskhod}\left(b_{i}=3.11\right)$, Yarok $\times$ Lvovskiy $\left(b_{i}=1.31\right)$ for fiber content. Low levels of variance stability was found in Velich $\left(\mathrm{S}^{2} \mathrm{~d}_{\mathrm{i}}=2.33\right)$, Lvovskiy 7 $\left(\mathrm{S}^{2} \mathrm{~d}_{\mathrm{i}}=4.62\right)$, Drakkar $\left(\mathrm{S}^{2} \mathrm{~d}_{\mathrm{i}}=6.18\right)$ for plant height; in Velich $\left(\mathrm{S}^{2} \mathrm{~d}_{\mathrm{i}}=5.37\right)$, Lvovskiy $7\left(\mathrm{~S}^{2} \mathrm{~d}_{\mathrm{i}}=4.62\right)$, Drakkar $\left(\mathrm{S}^{2} \mathrm{~d}_{\mathrm{i}}=6.20\right)$ for technical stem length; in Upite $2\left(\mathrm{~S}^{2} \mathrm{~d}_{\mathrm{i}}=1438.68\right)$, Yarok $\left(\mathrm{S}^{2} \mathrm{~d}_{\mathrm{i}}=3465.94\right)$, Lvovskiy $7\left(\mathrm{~S}^{2} \mathrm{~d}_{\mathrm{i}}=2268.62\right)$ for stem weight; in Vasilek $\left(\mathrm{S}^{2} \mathrm{di}=1.47\right)$, Upite $2\left(\mathrm{~S}^{2} \mathrm{~d}_{\mathrm{i}}=0.85\right)$, Drakkar $\left(\mathrm{S}^{2} \mathrm{~d}_{\mathrm{i}}=3.98\right)$, Voshod $\left(\mathrm{S}^{2} \mathrm{~d}_{\mathrm{i}}=3.65\right)$, Yarok $\left(\mathrm{S}^{2} \mathrm{~d}_{\mathrm{i}}=2.29\right)$ for the fiber content. High adaptable, stable and productive genotypes were few thereby necessitating further researches to create new breeding material.

Keywords: flax, varieties, hybrids, environmental adaptability, stability, productivity

Nowadays, the fiber flax selection is focused on improving resistance to biotic and abiotic factors while preserving the high productivity and quality of the feedstock. The main method in generating the parent material is still the intravariety hybridization which allows combining important traits of parents [1].

In the literature, there is sufficient information on the environmental study of varieties and hybrids of many crops, such as grains [2-7], corn [8, 9), lupine [10], rice [11], beet [12], clover [13], trees [14], sorghum [15], ornamental plants [16], sunflowers [17], potatoes [18], and tomatoes [19]. At the same time, there are extremely little papers dedicated to the environmental assessment of samples, 
varieties and, moreover, hybrid forms of fiber flax that actualizes these studies. A.B. D'yakov [20] highlights qualitative differences among flax ecotypes by their adaptability to soil and climate conditions, the specificity of plant competition in fiber and oil flax agrocoenosis, as well as the peculiarities of flax interactions with other biocenosis components. The agro-environmental assessment [21] has shown that the mid-ripening varieties of fiber flax selected in Pskov are the most adapted to natural conditions of the Northern Altai low-mountain terrain; therefore, the fiber flax has been considered a promising variety for the region. Detection of individual $L$. perenne plants in the arctic conditions of lower reaches of the $\mathrm{Ob}, \mathrm{Ye}-$ nisei, Lena and Indigirka rivers, as well as in the Polar and Middle Ural mountains, Yakutia and Altai (where the northern populations of perennial flax L. perenne grow as well) bears evidence of homologous parallelism between these species on their adaptability to arctic and high-mountain conditions and defines the possibility to select cultivated flax varieties adaptable to the northern territories [22]. The most adapted samples which are recommended to be selected for productivity, quality, resistance to lodging and diseases under various growing conditions have been identified in the fiber flax derived from Lithuania [23].

The flax productivity and yield depend on plant genetic diversity and the genotype $\times$ environment interaction [24]. Donors of a number of economically important traits have been found when studying the samples and highly productive forms adaptable to the conditions of the Nonchernozem Belt Central Area $[25,26]$. The flax growth and development intensity is also associated greatly with the pre-sowing soil treatment and the interaction between this factor and genotype. The emergence of flax seedlings depended considerably on temperature: the maximum germination $(87 \%)$ was observed at $30{ }^{\circ} \mathrm{C}$, the minimum one - at $10^{\circ} \mathrm{C}$ [27]. Under controlled conditions, the emergence of flax seedlings was even and quick at $30{ }^{\circ} \mathrm{C}$, while a photoperiod had no significant effect on the process [28].

V.Z. Bogdan [29] and L.M. Polonetskaya [30] were the first who studied the oil flax collection using statistical approaches and determined the impact which several factors had on trait formation. As a result, the authors have identified the genotypes adapted to the conditions of North-Eastern Belarus. L.V. Ivashko [31] and K.P. Korolev [32], having analyzed the variation of parmeters in different varieties, have found out the high environmental stability sources, i.e. Grant, Yarok, Vasilek, Vesta, Laska (Belarus), Drakkar, Alizee (France), Suzanne (the Netherlands).

In this work, we have identified the responsiveness of parent and hybrid forms of fiber flax to abiotic factors and the extent of their impact on the formation of traits such as plant height, technical stem length, stem weight and fiber content, for the first time in Belarus.

The purpose of our study was to assess forms of fiber flax by their environmental adaptability and stability in the conditions of North-Eastern Belarus.

Technique. Observations were made in 2012-2014, on the trial field (Orshansky Region, Vitebsk Province, Republic of Belarus). Flax plants were grown in sod-podzolic, light loamy soil underlied with moraine loam at the depth of $1 \mathrm{~m}$ (humus content 1.6-1.9\%, $\mathrm{P}_{2} 0_{5} 193.0-228.0 \mathrm{mg} / \mathrm{kg}, \mathrm{K}_{2} \mathrm{O} 107.0-219.0 \mathrm{mg} / \mathrm{kg}$, $\mathrm{pH}_{\mathrm{KCl}}$ 5.2-5.9) after grain crops as precursors. The study included the domestic varieties (Yarok, Laska, Vasilek, K-65, Velich) and those derived from France (Drakkar, Alizee), collection samples of Upite 2 (Lithuania), Voskhod (Russia), Lvovskiy 7 (Ukraine) (gene pool of the Flax Institute, Republic of Belarus), as well as $36 \mathrm{~F}_{2}-\mathrm{F}_{4}$ hybrid populations of fiber flax. Varieties of Yarok, Alei and Mogilevsky from Belarus served as standards. Hole sowing was carried out in the hybrid nursery (feeding area $2.5 \times 2.5 \mathrm{~cm}$ ) upon the optimum conditions. Parent forms were sown in 20 sets, with several guard rows at the beginning 
and end. Test arrangement, records and observations were carried out in accordance with the fiber flax selection guidelines [33].

Weather conditions differed in the years of trials. In 2012, the vegetation season was dry (lack of moisture at seedling-budding period), with high average daily temperature in the decade III of June-decade I of July, while in 2013 precipitations and air temperature were generally favorable. In 2014, precipitation fell out unevenly and temperature fluctuated: rains were $33 \%$ of the norm in rapid growth-blooming period, while during ripening when the total precipitations were $0.8 \mathrm{~mm}\left(3 \%\right.$ of the norm) the average temperature reached $23.5^{\circ} \mathrm{C}\left(6.2^{\circ} \mathrm{C}\right.$ above the climate norm).

Statistical processing was performed according to B.A. Dospekhov [34] using software packages of Microsoft Excel 2007 and Statistica 7 (StatSoft, Inc., USA). Plasticity index $\left(b_{i}\right)$ and stability variance $\left(\mathrm{S}^{2} \mathrm{~d}_{\mathrm{i}}\right)$ were assessed by S.A. Eberhart and W.A. Russell [35].

Results. The viability of genotypes selected as parent forms was associated with their high productivity, quality, resistance to lodging and fusarium wilt. They were preliminary studied under the conditions of North-Eastern Belarus. The standards were varieties Yarok, Alei and Mogilevsky adopted for commercial growing in Belarus which showed for a long time a lesser dependence on weather conditions as to principal economically important traits. Assessment of the whole set of studied traits using a two-way analysis of variance has proved the consistency of the genotype factor influence. For genotype $\times$ environment ineraction, the significance of mean square (MS) variation (linear) for fiber content was statistically unconfirmed, indicating similar responsiveness of genotypes to varied growing conditions, while for other traits the reliable interaction of the factors was found out (Table). At 95 and $99 \%$ confidence levels, genotypes maximally contributed to stem weight $(\mathrm{MS}=19361.41)$ and plant height $(\mathrm{MS}=7347)$. Environment mostly contributed to two traits, the stem weight $(\mathrm{MS}=343543.12$ ) and technical stem length $(\mathrm{MS}=8343.12)$.

Two-way analysis of variance on four target traits in fiber flax (Linum usitatissimum $\mathbf{L}$.) varieties and $\mathbf{F}_{\mathbf{2}}-\mathbf{F}_{\mathbf{4}}$ intervariety hybrids $(n=46$, Orshansky Region, Belarus, 2012-2014)

\begin{tabular}{|c|c|c|c|c|}
\hline \multirow{2}{*}{ Factor } & \multicolumn{4}{|c|}{ Mean square (MS) } \\
\hline & plant height & technical stem length & stem weight & fiber content \\
\hline Genotype & $73.47^{*}$ & $59.24^{*}$ & $19361.41^{*}$ & $10.79^{*}$ \\
\hline Environment & 22.70 & 17.41 & 5865.55 & 2.82 \\
\hline Environment (linear) & $3644.52 *$ & 8343.12 & 343543.12 & 150.16 \\
\hline Genotype $\times$ environment (linear) & $25.83^{*}$ & $17.96^{*}$ & $9231.85^{*}$ & 5.96 \\
\hline Pooled deviation from regression & 3.71 & 1.29 & 2214.41 & 1.41 \\
\hline
\end{tabular}

The most favorable growth conditions for fiber flax were in 2013 when the plant heights of K-65, Lvovskiy 7 varieties and Vasilek $\times$ K-65, Yarok $\times$ Voskhod, Vasilek $\times$ Drakkar hybrids reached $98.2 \mathrm{~cm}$. The high average daily air temperature during blooming in 2012 negatively affected generative organs and fertilization, but the year was the most favorable for the technical stem length: the maximum lengths we observed in Vasilek $\times$ Drakkar $(81.4 \mathrm{~cm})$, Yarok $(79.3$ $\mathrm{cm})$ and Voskhod $(77.3 \mathrm{~cm})$ varieties. The maximum stem weight was in 2014 as evidenced by parameters in the hybrid combinations involving Voskhod and Drakkar varieties.

The morphological analysis of hybrid forms has identified early ripening genotypes (in the combinations Yarok $\times$ Laska, Laska $\times$ K-65, Laska $\times$ Velich, Yarok $\times$ Upite 2, Yarok $\times$ Drakkar, Yarok $\times$ Vasilek, Yarok $\times$ Voskhod, Voskhod $\times$ Lvovskiy 7 , Voskhod $\times$ Laska, Voskhod $\times$ Velich; Yarok $\times$ Alizee) and tall-growing genotypes (Yarok $\times$ Velich, Vasilek $\times$ K-65, Laska $\times$ Yarok, 
Yarok $\times$ Velich, Alizee $\times$ Upite 2, Upite $2 \times$ Drakkar, Laska $\times$ Drakkar, Upite $2 \times$ Vasilek, Upite $2 \times$ Yarok, K-65 $\times$ Yarok, K-65 $\times$ Drakkar, Velich $\times$ Alizee, Voskhod $\times$ Yarok, Laska $\times$ Voskhod, Voskhod $\times$ Alizee); genotypes having the maximum technical stem length (Upite $2 \times$ Laska, Upite $2 \times$ Drakkar, Yarok $\times$ Velich, Voskhod $\times$ Yarok, Voskhod $\times$ Alizee, Velich $\times$ Alizee, Voskhod $\times$ K-65, Laska $\times$ Yarok, Yarok $\times$ Velich, Alizee $\times$ Upite 2) and the maximum stem weight (Alizee $\times$ Upite 2, Upite $2 \times$ Drakkar, Laska $\times$ Yarok, Yarok $\times$ Velich), the maximum fiber weight (Laska $\times$ Yarok, Yarok $\times$ Velich, Alizee $\times$ Upite 2, Voskhod $\times$ K-65, Upite $2 \times$ Drakkar), and the maximum fiber content (Yarok $\times$ Velich, Upite $2 \times$ Drakkar, Alizee $\times$ Upite 2).

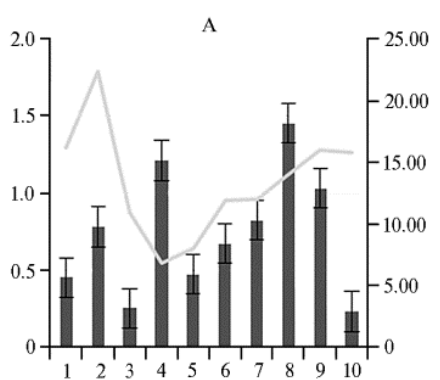

$\mathrm{C}$

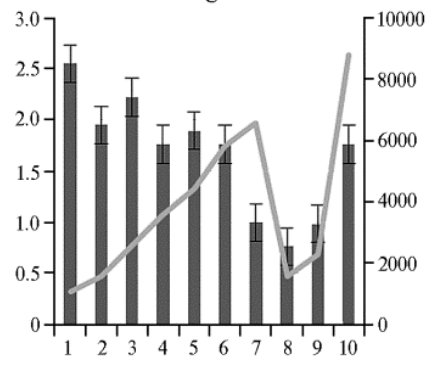

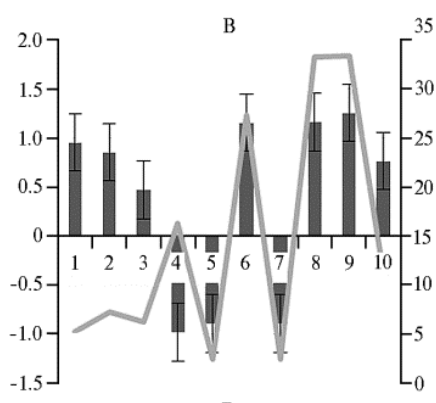

$\mathrm{D}$

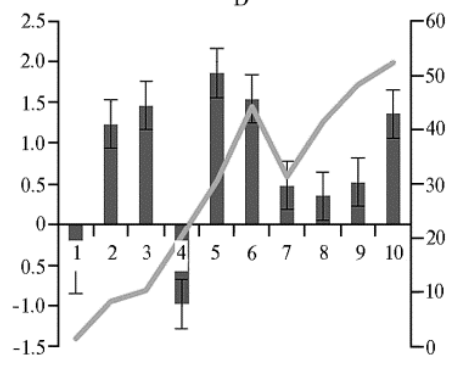

Adaptability and stability of parental varieties of fiber flax (Linum usitatissimum L.) on plant height (A), technical stem length (B), stem weight $(C)$ and fiber content (D): 1 - Vasilek, 2 - Lvovskiy 7, 3 Upite 2, 4 - Velich, 5 K-65, 6 - Drakkar, 7 Alizee, 8 - Voskhod, 9 Laska, 10 - Yarok; plasticity index $b_{i}$ is provided by diagrams (left scale), stability variance $\mathrm{S}^{2} \mathrm{~d}_{\mathrm{i}}$ is shown by curves (right scale) (Orshansky Region, Belarus, 2012-2014).

Among all parental forms (Fig.), the minimum variability for plant height was observed in Yarok

$\left(b_{i}=0.45, S^{2} d_{i}=16.21\right)$, Voskhod $\left(b_{i}=0.25, S^{2} d_{i}=10.92\right), K-65\left(b_{i}=0.67\right.$, $\left.\mathrm{S}^{2} \mathrm{~d}_{\mathrm{i}}=11.90\right)$, Vasilek $\left(\mathrm{b}_{\mathrm{i}}=0.23, \mathrm{~S}^{2} \mathrm{~d}_{\mathrm{i}}=15.78\right)$ varieties, for technical stem length in Voskhod $\left(b_{i}=0.47, \mathrm{~S}^{2} \mathrm{~d}_{\mathrm{i}}=6.23\right)$, Vasilek $\left(\mathrm{b}_{\mathrm{i}}=0.23, \mathrm{~S}^{2} \mathrm{~d}_{\mathrm{i}}=15.78\right)$, Velich (bi $\left.=0.89, \mathrm{~S}^{2} \mathrm{~d}_{\mathrm{i}}=2.45\right)$, Drakkar $\left(\mathrm{b}_{\mathrm{i}}=0.89, \mathrm{~S}^{2} \mathrm{~d}_{\mathrm{i}}=2.45\right)$, for stem weight in Upite $2\left(b_{i}=0.76, S^{2} d_{i}=1553.86\right)$, Lvovskiy $7\left(b_{i}=0.98, S^{2} d_{i}=2268.64\right)$, for fiber content in Velich $\left(b_{i}=0.48, S^{2} d_{i}=31.2\right)$, Upite $2\left(b_{i}=0.35, S^{2} d_{i}=41.5\right)$. Among hybrid combinations, the adaptability on plant height was identified in Yarok $\times$ Laska $\left(b_{i}=0.67, \mathrm{~S}^{2} d_{i}=12.33\right)$, Yarok $\times \operatorname{Voskhod}\left(b_{i}=0.87, \mathrm{~S}^{2} d_{i}=12.33\right)$, Voskhod $\times$ Yarok $\left(b_{i}=0.83, S^{2} d_{i}=32.31\right)$, Voskhod $\times$ Laska $\left(b_{i}=0.83\right.$, $\left.\mathrm{S}^{2} \mathrm{~d}_{\mathrm{i}}=32.31\right)$, Velich $\times$ Yarok $\left(\mathrm{b}_{\mathrm{i}}=0.23, \mathrm{~S}^{2} \mathrm{~d}_{\mathrm{i}}=12.34\right)$, on technical stem length in Velich $\times$ Alizee $\left(b_{i}=0.53, S^{2} d_{i}=34.43\right)$, Voskhod $\times$ Yarok $\left(b_{i}=0.54\right.$, $\left.\mathrm{S}^{2} \mathrm{~d}_{\mathrm{i}}=2.45\right)$, Laska $\times$ Voskhod $\left(\mathrm{b}_{\mathrm{i}}=0.31, \mathrm{~S}^{2} \mathrm{~d}_{\mathrm{i}}=56.78\right)$, Laska $\times$ Drakkar $\left(b_{i}=0.12, S^{2} d_{i}=11.43\right)$, on stem weight in Yarok $\times$ Upite $2\left(b_{i}=0.78\right.$, $\left.\mathrm{S}^{2} \mathrm{~d}_{\mathrm{i}}=3243.12\right)$, Upite $2 \times$ Drakkar $\left(\mathrm{b}_{\mathrm{i}}=0.14, \mathrm{~S}^{2} \mathrm{~d}_{\mathrm{i}}=2256.78\right)$, Yarok $\times$ Lvovskiy $7\left(b_{i}=0.43, S^{2} d_{i}=1237.01\right)$, on fiber content in Yarok $\times$ Velich $\left(b_{i}=0.76\right.$, $\left.\mathrm{S}^{2} \mathrm{~d}_{\mathrm{i}}=4.56\right)$, Laska $\times$ Velich $\left(\mathrm{b}_{\mathrm{i}}=0.56, \mathrm{~S}^{2} \mathrm{~d}_{\mathrm{i}}=3.23\right)$, and $\mathrm{K}-65 \times$ Upite 2 $\left(b_{i}=0.32, S^{2} d_{i}=2.34\right)$.

Currently, due to climate changes, screening for adaptability and stability is considered an important step in selection. As L.V. Ivashko [31] notes, Yarok and Vasilek varieties surpass foreign analogues in productivity and tolerance to unfavorable environment factors in a number of cases. However, foreign varieties possessing both high productivity and lodging resistance should be involved in 
crossings to enhance the genetic diversity of novel varieties. Adaptable forms among collection samples of fiber and oil flax was reported by K.P. Korolev [32], V.Z. Bogdan et al. [29] and L.M. Polonetskaya [30] based on environmental studies in Belarus. It is consistent with the findings of foreign researchers [26] who identified trait variability in 1117 collection samples of flax.

It should be noted a local variety in the parentage of varieties bred in Belarus (Yarok, Vasilek, Laska, Velich, K-65) that makes it possible to obtain hybrids with both productivity and resistance to unfavorable environment factors without a decrease in the trait expression.

Thus, the varieties developed in Belarus and the majority of their hybrids appeared to be more stable in the varied environment conditions than foreign varieties. The stability in plant height and technical stem length was characteristic of Voskhod, Yarok, K-65 while technical stem length, stem weight and fiber content stability were observed in Vasilek, Velich, Drakkar and Upite 2. Upite 2, Velich, Drakkar, Lvovskiy 7, Laska, and Alizee varieties may be referred to genotypes well responded to improved environmental conditions $\left(b_{i}>1\right)$ on plant height, stem weight, and fiber content. High adaptability on all the studied traits was characteristic of Laska and Alizee varieties. As a result of our trials conducted in North-Eastern Belarus, the varieties Yarok, Vasilek, Velich, K-65, Upite 2, and hybrid combinations Laska $\times$ Yarok, Yarok $\times$ Velich, Alizee $\times$ Upite 2, Voskhod $\times$ K-65, Upite $2 \times$ Drakkar, Laska $\times$ Velich, K-65 $\times$ Upite 2 may be used to develop novel flax varieties having high productivity and resistance to unfavorable environmental factors.

\section{REFERENCES}

1. Geneticheskie osnovy selektsii rastenii [Genetic fundamentals of plant breeding]. A.V. Kil'chevskii, L.V. Khotyleva (eds.). Minsk, 2008 (in Russ.).

2. B o m e N.A., Ri p be rge r E.I., D i e t e r T. Ekologiya i prirodopol'zovanie, 2015, 1(1/1): 98107 (in Russ.).

3. Ripberge r E.I., B o me N.A., Trautz D. Vavilovskii zhurnal genetiki i selektsii, 2015, 19(2): 185-190 (in Russ.).

4. Ri pberger E.I., B o me N.A., Trautz D. Variation in the plant height of spring common wheat (Triticum aestivum L.) hybrid forms under different ecological and geographical conditions. Russian Journal of Genetics: Applied Research, 2016, 6(3): 258-263.

5. Riabchun V.K., Melnyk V.S., Kapustina T.B., Shchechenko O.Ye. Sortovivchennya ta okhorona prav na sorti roslin (Ukraine), 2016, 1(30): 37-44.

6. Madry W., Paderewski J., Rozbicki J., Gozdowski D., Golba J., Piechocinski M., Studnicki M., Derejko A. Yielding of winter wheat cultivars across environments - one-year multi-environment post-registration trial. Biul. Inst. Hodowli Aklimat. Roslin, 2012, 263: 189-204.

7. Z a m fi r M.C., Z a m fir I. Studiul comportarii unor soiuri de grau in conditiile pedoclimatice din campia Burnasului. Univ. de Stiinte Agronomice si Medicina Veterinara. Ser. A: Agronomie, 2004, 45: 82-90.

8. Silva R.G., Cruz C.D., Mirand a G.V., G a lva o J.C.C., S ilva D.G. Adaptabilidade de familias de meio-irmaos de milho submetidas ao deficit hidrico e baixa disponibilidade denitrogenio. Revista Ceres, 2008, 55(4): 344-351.

9. Brito A.R. de M., Tabosa J.N., D e Carvalho H.W.L., Dos Santos M.X., T a vare s J.A. Adaptability and stability of corn cultivars in the State of Pernambuco, Brazil. Revista Ciencia Agronomica, 2005, 36(3): 348-353.

10. Ag a rk ova S.N. Vestnik Orlovskogo agrarnogo universiteta, 2012, 3: 41-44 (in Russ.).

11. Matsushita K., Ishii T., Ideta O., Iida S., Sunohara Y., Ma eda H., Wat a na b e H. Yield and lodging resistance of Tachiayaka, a novel rice cultivar with short panicles for whole-crop silage. Plant Product Science, 2014, 17(2): 202-206 (doi: 10.1626/pps.17.202).

12. Oshevnev V.P., Gribanova N.P., Kolosova N.N., Samodurova N.I., Novikova L.N. Sakharnaya svekla, 2009, 6: 12-15 (in Russ.).

13. Bekuzarova S.A., Samova I.T., Tsopanova F.T. Izvestiya Gorskogo gosudarstvennogo agrarnogo universiteta, 2010, 47(1): 40-43 (in Russ.).

14. Rousi M., Heinonen J., $\mathrm{Neuv}$ one $\mathrm{n}$ S. Intrapopulation variation in flowering phenolo- 
gy and fecundity of silver birch, implications for adaptability to changing climate. Forest Ecol. Manag., 2011, 262(12): 2378-2385 (doi: 10.1016/j.foreco.2011.08.038).

15. R a o P.S., Re d d y P.S., R a th o re A., Vs R e d d y B., P a n w a r S. Application GGE biplot and AMMI model to evaluate sweet sorghum (Sorghum bicolor) hybrids for genotype $\times$ environment interaction and seasonal adaptation. Ind. J. Agr. Sci., 2011, 81(5): 438-444.

16. N e d olu z h k o A.I. Sibirskii vestnik sel'skokhozyaistvennoi nauki, 2010, 11: 43-50 (in Russ.).

17. Dyakov A.B., B a rs u k ov A.A Maslichnye kul'tury, 2014, 2: 3-26 43-50 (in Russ.).

18. S t r e l't s o va T.A., D o b r u t s k y a E.G. Vestnik rossiiskoi sel'skokhozyaistvennoi nauki, 2008, 6: 59-61 (in Russ.).

19. N a c h e va E. Evaluation for yield, stability and adaptability of mid-late potato lines and varieties. Genet. Breed., 2010, 39(1-2): 181-185.

20. D'y a k ov A.B. Fiziologiya $i$ ekologiya l'na [Physiology and ecology of flax]. Krasnodar, 2006 (in Russ.).

21. S h tab el Yu.P., P o p e l y a y v a N.N. Vestnik Altaiskogo gosudarstvennogo agrarnogo universiteta, 2013, 1: 54-56 (in Russ.).

22. Luk o met s V.M., Ze le n t s ov S.V., Ryabenko L.G. Maslichnye kul'tury, 2015, 1: 121132 (in Russ.).

23. Razukas A., Jankauskiene Z., Jundulas J., As akaviciute R. Research of technical crops (potato and flax) genetic resources in Lithuania. Agronomy Research, 2009, 7(1): 59-72.

24. Diederichsen A., Ulrich A. Variability in stem fibre content and its association with other characteristics in 1177 flax (Linum usitatissimum L.) genebank accessions. Ind. Crops Prod., 2009, 30(1): 33-39 (doi: 10.1016/j.indcrop.2009.01.002).

25. Rozhmina T.A., Pavlova L.N., K u z e mk in I.A., Rizhov A.I. Trudy Kubanskogo gosudarstvennogo agrarnogo universiteta, 2015, 54: 263-267 (in Russ.).

26. Diederichsen A., Rozhmina L., Kudrjavceva A. Variation patterns within 153 flax (Linum usitatissimum L.) genebank accessions based on evaluation for resistance to fusarium wilt, anthracnose and pasmo. Plant Genetic Resources, 2008, 6: 22-32 (doi: 10.1017/S1479262108913897).

27. Kurt O., Bozkurt D. Effect of temperature and photoperiod on seedling emergence of flax. Journal of Agronomy, 2006, 5: 541-545 (doi: 10.3923/ja.2006.541.545).

28. D a rapuneni M.K., M orga n G.D., I b rahim A.M., Duncan W.R. Effect of vernalization and photoperiod on flax flowering time. Euphytica, 2014, 195: 279-285 (doi: 10.1007/s10681-013-0996-x).

29. B og d a n V.Z., P o lo ne t s a y a L.M. Vestsi NAN Belarusi. Seryya biyalagichnykh navuk, 2009, 1: $72-78$ (in Russ.).

30. Polo nets k a y L.M. Vestsi NAN Belarusi. Seryya biyalagichnykh navuk, 2009, 2: 22-27 (in Russ.).

31. Ivash ko L.V. Vestnik Belorusskoi gosudarstvennoi sel'skokhozyaistvennoi akademii, 2013, 4: 95-99 (in Russ.).

32. K o r o le v K.P. Vestnik Belorusskoi gosudarstvennoi sel'skokhozyaistvennoi akademii, 2014, 4: 131135 (in Russ.).

33. Pavlova L.N., A le ks a ndrova T.A. Metodicheskie ukazaniya po selektsii l'na-dolguntsa [Recommendations on flax breeding]. Moscow, 2004 (in Russ.).

34. D o s p e k h o v B.A. Metodika polevogo opyta [Methods of field trials]. Moscow, 1972 (in Russ.).

35. Eberhart S.A., Russe 11 W.A. Stability parameters for comparing varieties. Crop Sci., 1966, 6: 36-40. 